\title{
Human Granulocyte-Macrophage Colony-stimulating Factor Induces Expression of the Tumor Necrosis Factor Gene by the U937 Cell Line and by Normal Human Monocytes
}

Stephen A. Cannistra, Alessandro Rambaldi, David R. Spriggs, Friedhelm Herrmann, Donald Kufe, and James D. Griffin

Division of Tumor Immunology, Dana-Farber Cancer Institute, Harvard Medical School, Boston, Massachusetts 02115

\begin{abstract}
Human granulocyte-macrophage colony-stimulating factor (GMCSF) exerts profound effects on the proliferation, differentiation, and effector function of myeloid lineage cells. In contrast to its growth-promoting effects on normal myeloid progenitor cells, we found that GM-CSF unexpectedly inhibited the colony growth of $\mathbf{U} 937$ cells in agar culture. Furthermore, medium conditioned by recombinant GM-CSF(rGM-CSF)-treated U937 cells was found to exert an inhibitory effect on subsequent U937 colony growth that was partially due to the presence of tumor necrosis factor (TNF). By Northern blot analysis, rGM-CSF was shown to induce expression of the TNF gene in U937 cells and in Tlymphocyte-depleted, monocyte-enriched peripheral blood mononuclear cells. Furthermore, rGM-CSF was observed to significantly enhance TNF secretion by monocytes stimulated with endotoxin and phorbol myristate acetate (PMA). These data suggest that some of the biological effects of GM-CSF may be amplified through the release of monokines such as TNF.
\end{abstract}

\section{Introduction}

Colony-stimulating factors (CSFs) ${ }^{1}$ are a heterogeneous group of glycoproteins that are required for the proliferation and differentiation of hematopoietic progenitor cells in vitro. The gene for human granulocyte-macrophage CSF (GM-CSF) has been cloned, and recombinant GM-CSF (rGM-CSF) has been shown to support the growth of progenitor cells for granulocytes, erythrocytes, macrophages, megakaryocytes, and eosinophils $(1,2)$. In addition to effects on the growth of early progenitor cells, GM-CSF enhances the effector functions of mature cells of the granulocyte-macrophage series. For example, GM-CSF has been shown to inhibit neutrophil migration (3), stimulate neutrophil phagocytosis (4), and enhance macrophage tumoricidal activity in vitro (5). The mechanisms whereby GM-CSF induces such

Address reprint requests to Dr. S. A. Cannistra, Division of Tumor Immunology, Dana-Farber Cancer Institute, 44 Binney Street, Boston, MA 02115. 1987.

Received for publication 20 August 1986 and in revised form 9 January

1. Abbreviations used in this paper: CM, conditioned media; FBS, fetal bovine serum; GM-CSF, granulocyte-macrophage colony-stimulating factor, IFN-gamma, gamma-interferon; PGE and PGE1, prostaglandin $\mathrm{E}$ and $\mathrm{E} 1$; rGM-CSF, recombinant GM-SCF; rIL-1, recombinant interleukin 1; TNF, tumor necrosis factor.

J. Clin. Invest.

(c) The American Society for Clinical Investigation, Inc.

0021-9738/87/06/1720/09 \$1.00

Volume 79, June 1987, 1720-1728 pleiotropic effects have not been determined, although it is likely that the initial step involves binding of GM-CSF to specific, high affinity surface receptors that are present on both early myeloid progenitor cells as well as on differentiated cells of the granulocyte-macrophage series (6).

In an effort to study the mechanisms of action of GM-CSF, we have investigated the effects of this growth factor on the proliferation and differentiation of the U937 monocytic cell line. We report that GM-CSF is inhibitory to the proliferation of U937 cells, and that this inhibition is associated with the secretion of biologically active tumor necrosis factor (TNF). Furthermore, we also show that GM-CSF enhances TNF secretion of normal human blood monocytes that are induced by endotoxin and phorbol myristate acetate (PMA).

\section{Methods}

Cell lines and human mononuclear cells. Cell lines used in this study (U937 (7), HL60 (8), KG-1 (9), K562 (10), and Daudi (11)) were obtained from the American Type Culture Collection (Rockville, MD) and cultured in RPMI 1640 medium (Gibco, Grand Island, NY) that was supplemented with $10 \%$ fetal bovine serum (FBS). Peripheral blood cells were obtained from volunteer donors and mononuclear cell suspensions were prepared by Ficoll-Hypaque density gradient centrifugation. T-lymphocytes were depleted by $E$ rosetting to enrich peripheral blood monocytes ( $\mathrm{E}^{-}$fraction). The composition of the $\mathrm{E}^{-}$fraction was determined by indirect immunofluorescence staining with monoclonal anti-Mo2, -HLA-DR, -T11, -B1, and -NKH1 (12) antibodies, and was found to contain 75-85\% Mo2-, 70-80\% HLA-DR-, 0-1\% T11-, 3-5\% B1-, and 5-8\% NKH1-positive cells.

Biological reagents. IGM-CSF was a gift from Dr. S. Clark, Genetics Institute, Cambridge, MA, and had been purified to a single band $(\sim 2.5$ $\times 10^{6} \mathrm{pg} / \mathrm{ml}$ and $2 \times 10^{9} \mathrm{U} / \mathrm{mg}$ protein sp act) from medium conditioned by $C O S$ cells transfected with the $p 91203$ vector that contained the GMCSF complementary DNA (cDNA) (1). Units of colony-stimulating activity were calculated from the dose-response curve of rGM-CSF concentration for normal bone marrow colony growth, with $50 \mathrm{U} / \mathrm{ml}$ the concentration that stimulated the formation of $50 \%$ maximal colony growth (4). Human recombinant granulocyte CSF and recombinant macrophage CSF were also provided by Drs. Clark and G. Wong, and were used at final dilutions of $1: 1,000$ and $1: 500$ of $C O S$ cell supernatant, respectively. These concentrations were found to support the maximum growth of either human granulocyte or murine macrophage colonies in agar culture. Anti-GM-CSF sheep serum, also provided by Dr. Clark, was prepared against purified rGM-CSF and reacted with a single broad band (apparent molecular mass 19-26 kD) by Western blot analysis. For some experiments, "mock" CSF (supernatant from COS cells transfected with vector DNA only) was used for control purposes. The endotoxin concentrations of stock rGM-CSF, mock CSF, and the medium (RPMI 1640 with $10 \%$ FBS) used in this study were $0.5,0.5$, and 0.3 $\mathrm{ng} / \mathrm{ml}$, respectively (kindly measured by Dr. R. N. Berzofsky, M. A. Bioproducts, Walkersville, MD). Human recombinant TNF (rTNF, PAC4D) was generously provided by the Asahi Chemical Industry, Shizuoka, Japan, and had a $2.2 \times 10^{6} \mathrm{U} / \mathrm{mg}$ sp act as defined by its cytotoxic effects on actinomycin D-treated L929 mouse fibroblast cells (13). Purified 
mouse monoclonal anti-TNF antibody (IgG1) was also provided by Asahi Chemical Industry for blocking studies. Monoclonal antibody to interferon-gamma (IFN-gamma) (clone $3 \mathrm{Cl1C8}, \mathrm{IgG} 1$ ) was produced in our laboratory as previously described (14) and used as a control in blocking experiments. $10^{3} \mathrm{U} / \mathrm{ml} \mathrm{sp}$ act recombinant interleukin 1 (rIL-1) alpha and beta were obtained from Genzyme Corp., Boston, MA. PGE , indomethacin, lipopolysaccharide (Escherichia coli 0111:B4), and PMA were purchased from Sigma Chemical Co., St. Louis, MO.

Colony assay. Cell lines were plated at $5 \times 10^{2}$ cells per $1 \mathrm{ml}$ culture in Iscove's modified Dulbecco's minimal essential media (Gibco) that contained $20 \%$ FBS and $0.3 \%$ agar over an underlayer of $0.5 \%$ agar as previously described (15). Indomethacin at a final concentration of $10^{-6}$ $M$ was routinely added to prevent endogenous prostaglandin production. The effects of rGM-CSF, rTNF, rIL-1 alpha and beta, and PGE Pn $_{1}$ colony growth were assayed in this system during a 7-d incubation period $\left(37^{\circ} \mathrm{C}, 5 \% \mathrm{CO}_{2}\right)$. In some experiments, blocking antibodies (anti-GM$\mathrm{CSF}$, anti-TNF) were added and allowed to incubate for $1 \mathrm{~h}$ at $25^{\circ} \mathrm{C}$ before final plating. At day seven, overlayers were harvested, dried on glass microscope slides, fixed in methanol for $1 \mathrm{~min}$, and stained with Gill's hematoxylin for 15 min (Fisher Scientific Co., Fair Lawn, NJ). Colonies ( 40 cells) and clusters (8-40 cells) were counted and the data expressed as mean \pm SEM of duplicate or triplicate cultures.

Conditioned media (CM) preparation. To evaluate the possibility that a soluble inhibitor was secreted by U937 cells in response to rGMCSF, U937 cells at a final concentration of $2.5 \times 10^{5}$ cells $/ \mathrm{ml}$ were incubated in $10 \%$ FBS with RPMI 1640 and $10^{-6} \mathrm{M}$ indomethacin, with or without $250 \mathrm{pg} / \mathrm{ml} \mathrm{rGM-CSF}$, for 24, 48, and $72 \mathrm{~h}$ in Linbro 24-well plates (Flow Laboratories, Inc., McLean, VA). At each point in time, supernatants were collected and frozen at $-70^{\circ} \mathrm{C}$ until use. For some experiments, U937 cells were collected at each point in time for evaluation of surface marker expression and cell cycle status as outlined below. Cell recovery and viability were always $>95 \%$.

Immunofluorescence analysis of surface markers. Indirect immunofluorescence assays were performed as previously described (15), using monoclonal anti-HLA-DR, anti-Mol and anti-Mo2 (12) antibodies. Negative control antibodies were matched for Ig subclass and used at equivalent concentrations. Flow cytometric analysis was performed on an Epics C cell sorter (Coulter Electronics, Inc., Hialeah, FL).

Cell cycle analysis. DNA histogram analysis of U937 cells was performed as previously described $(16,17)$. Briefly, $0.5 \times 10^{6}$ cells were stained with $50 \mu \mathrm{g} / \mathrm{ml}$ propidium iodide (Sigma Chemical Co.) in $0.1 \%$ sodium citrate and 0.1\% NP-40 (Particle Data, Inc., Elmhurst, IL). Cells were incubated for $20 \mathrm{~min}$ at $4^{\circ} \mathrm{C}$ to allow for hypotonic lysis of cell membranes, while leaving nuclei intact. The nuclei $(10,000$ per sample) were analyzed on an Epics $C$ cell sorter, and analysis of DNA histograms was performed by using the PARA-1 computer program (Coulter Electronics, Inc.)

Preparation of total cellular RNA and Northern blot analysis. Total cellular RNA was isolated, as previously described (18), by lysing cells in guanidium isothiocyanate and recovering RNA by centrifugation through cesium chloride. 20- $\mu$ g samples were then fractionated on a $1.2 \%$ agarose gel with $6 \%$ formaldehyde and blotted onto Gene Screen Plus synthetic membranes (New England Nuclear, Boston, MA). TNF message was detected by using a specific TNF cDNA probe, the 1.1 kilobase (kb) Pst-1 fragment of TNF (plasmid pE4, kindly provided by Drs. D. Mark and P. Ralph, Cetus Corp., Emeryville, CA) (19). This cDNA probe was labeled $10^{9} \mathrm{cpm} / \mu \mathrm{g}$ sp act by using hexanucleotide primers and $\left[{ }^{32} \mathrm{P}\right] \mathrm{dCTP}(20)$. Hybridization was performed for $20 \mathrm{~h}$ at $60^{\circ} \mathrm{C}$ in a solution that contained $1 \mathrm{M} \mathrm{NaCl}, 1 \%$ sodium dodecyl sulfate (SDS), $10 \%$ dextran sulfate, $100 \mu \mathrm{g} / \mathrm{ml}$ salmon sperm DNA, and $1 \times 10^{6}$ $\mathrm{cpm} / \mathrm{ml}$-labeled probe. The membrane was washed with $2 \times$ standard saline citrate (SSC)/1\% SDS for $1 \mathrm{~h}$ at $65^{\circ} \mathrm{C}$ and $0.1 \times \mathrm{SSC}$ at room temperature for $1 \mathrm{~h}(1 \times \mathrm{SSC}=0.15 \mathrm{M} \mathrm{NaCl}$ and $0.015 \mathrm{M} \mathrm{Na}$ citrate, pH 7.0). The blots were then dried and used to expose Kodak Xomat $\mathrm{x}$-ray film with intensifying screens.

Measurements of TNF. For some experiments, the TNF concentration of cell-free supernatant was measured by using a modification of an enzyme-linked immunosorbent assay (ELISA) developed by the Asahi Chemical Industry (21). Two murine monoclonal antibodies that reacted with separate epitopes on the TNF molecule were utilized. The first antibody was bound to the 96-well plate with $0.05 \mathrm{M} \mathrm{Na}_{2} \mathrm{CO}_{3}$, $\mathrm{pH} 9.5$. After incubating the plates at $4^{\circ} \mathrm{C}$ overnight, they were washed twice with $0.05 \%$ Tween in phosphate-buffered saline (PBS). The wells were then blocked for $2 \mathrm{~h}$ at $25^{\circ} \mathrm{C}$ with $20 \%$ horse serum to prevent nonspecific binding of the second monoclonal antibody. After washing twice, 200 $\mathrm{ml}$ each of TNF standards and test samples were plated in triplicate wells and incubated at $4^{\circ} \mathrm{C}$ for $18 \mathrm{~h}$. The plates were washed again and the second antibody, bound to horseradish peroxidase, was added. After incubating the plates for $6 \mathrm{~h}$ at $25^{\circ} \mathrm{C}$, they were washed twice, and $O$ phenylenediamine $/ \mathrm{H}_{2} \mathrm{O}_{2}$ (Sigma Chemical Co.) in sodium citrate-phosphate buffer (Fisher Scientific Co., Allied Corp.) was added (30 mg $O$ phenylenediamine per $20 \mathrm{ml}$ citrate-phosphate buffer, pH 5 , with $7 \mu \mathrm{l}$ $30 \% \mathrm{H}_{2} \mathrm{O}_{2}$ ). The plates were then developed at $25^{\circ} \mathrm{C}$ for $5 \mathrm{~min}$; the reaction terminated with $4.5 \mathrm{M} \mathrm{H}_{2} \mathrm{SO}_{4}$. The absorbance was read at 492 $\mathrm{nm}$ on an ELISA Reader (Bio-Rad Laboratories, Richmond, CA) and a standard curve was computed. The TNF concentration in test samples was determined from the standard curve and expressed as units per milliliter, with $1 \mathrm{U} / \mathrm{ml}$ TNF defined as the amount necessary to kill $50 \%$ of actmonycin D-treated L929 mouse fibroblasts after $18 \mathrm{~h}$ as previously described (13).

\section{Results}

Effects of rGM-CSF on colony growth of hematopoietic cell lines. The effects of rGM-CSF on the growth of U937, HL60, KG-1, $\mathrm{K} 562$, and Daudi cell lines were evaluated in double layer agar culture in a $2.5-2500 \mathrm{pg} / \mathrm{ml}$ rGM-CSF-dose range (Table I). rGM-CSF did not significantly influence the colony growth or

Table I. Effects of rGM-CSF on Colony Growth of Hematopoietic Cell Lines

\begin{tabular}{|c|c|c|c|c|c|}
\hline \multirow[b]{3}{*}{ Cell line } & \multicolumn{5}{|c|}{ Colonies per $5 \times 10^{2}$ cells* } \\
\hline & \multicolumn{5}{|c|}{$\mathrm{rGM}-\mathrm{CSF}(\mathrm{pg} / \mathrm{ml})$} \\
\hline & 0 & 2,500 & 250 & 25 & 2.5 \\
\hline U937 & $111 \pm 10^{\ddagger}$ & $1 \pm 0 \quad(99)^{\S}$ & $5 \pm 1 \quad(95)$ & $17 \pm 2$ & $83 \pm 2 \quad(25)$ \\
\hline HL60 & $88 \pm 11$ & $75 \pm 10(15)$ & $92 \pm 9 \quad(-5)$ & $94 \pm 10(-7)$ & $89 \pm 10(-1)$ \\
\hline KG-1 & $132 \pm 14$ & $137 \pm 12(-4)$ & $141 \pm 19(-7)$ & $138 \pm 16(-5)$ & $130 \pm 10(2)$ \\
\hline K562 & $143 \pm 16$ & $148 \pm 20(-3)$ & $146 \pm 13(-2)$ & $142 \pm 12(1)$ & $138 \pm 15(3)$ \\
\hline Daudi & $172 \pm 21$ & $168 \pm 19(2)$ & $175 \pm 18(-2)$ & $174 \pm 16(-1)$ & $172 \pm 17(0)$ \\
\hline
\end{tabular}

* Cells were plated in a double-layer colony assay and incubated in varying concentrations of rGM-CSF $\left(37^{\circ} \mathrm{C}, 5 \% \mathrm{CO}_{2}\right)$ for $7 \mathrm{~d}$. ${ }^{\ddagger} \mathrm{Results}$ are expressed as mean \pm SEM colonies of triplicate cultures. Numbers in parentheses indicate percent inhibition. 
Table II. Inhibitory Effect of rGM-CSF on U937 Colony Growth Reversed by Anti-rGM-CSF Sheep Serum

\begin{tabular}{llll}
\hline & \multicolumn{2}{l}{ Colonies per $5 \times 10^{2}$ U937 cells* } & Anti-GM-CSF (1:1,000) \\
\cline { 2 - 4 } Treatment & Control & Anti-GM-CSF $(1: 100)^{*}$ & $159 \pm 20$ \\
Media & $158 \pm 14^{8}$ & $150 \pm 18$ & ND \\
Mock CSF $(1: 100)^{\prime \prime}$ & $155 \pm 12$ & ND & $123 \pm 14$ \\
rGM-CSF $(250 \mathrm{pg} / \mathrm{ml})$ & $7 \pm 2$ & $148 \pm 16$ & $116 \pm 7$ \\
rGM-CSF $(2,500 \mathrm{pg} / \mathrm{ml})$ & $1 \pm 0$ & $138 \pm 12$ & ND \\
Endotoxin' $(0.5 \mathrm{ng} / \mathrm{ml})$ & $161 \pm 20$ & $158 \pm 11$ & ND \\
Endotoxin $(1.0 \mathrm{ng} / \mathrm{ml})$ & $145 \pm 16$ & $143 \pm 10$ & \\
\hline
\end{tabular}

* See Table I. ${ }^{\ddagger}$ Anti-rGM-CSF sheep was added to the above treatment groups and incubated at $25^{\circ} \mathrm{C}$ for $1 \mathrm{~h}$ before the addition of U937 cells. ${ }^{8}$ Results are expressed as mean \pm SEM of duplicate cultures. "Mock CSF refers to vector-only transfected COS cell supernatant and contains no CSF activity in agar culture. 'LPS from $E$. coli serotype 0111:B4.

morphology of HL60, KG-1, K562, or Daudi cells during a 7d culture period. In contrast, U937 colony and cluster formation was inhibited in a dose-dependent fashion by GM-CSF (Table I). The dose of rGM-CSF that inhibited 50\% of U937 colony growth (ineffective dose $\left[\mathrm{ID}_{50}\right]$ ) was $\sim 10 \mathrm{pg} / \mathrm{ml}$. As shown in Table II, preincubation of rGM-CSF with anti-GM-CSF sheep serum for $1 \mathrm{~h}$ at $25^{\circ} \mathrm{C}$ before plating resulted in significant restoration of colony growth. Neither mock CSF nor endotoxin (E. coli 0111:B4) treatment significantly affected U937 colony growth at the concentrations tested (Table II). In contrast to the inhibitory effects of rGM-CSF on U937 proliferation in agar culture, neither recombinant G-CSF nor recombinant M-CSF significantly affected U937 colony growth at dilutions of $1: 1,000$ or 1:500, respectively (data not shown).

Effects of recombinant GM-CSF on proliferation and differentiation of U937 cells in suspension culture. To further characterize the response of the U937 cell line to rGM-CSF, an initial concentration of $3.0 \times 10^{5}$ cells/ml in $10 \%$ FBS with RPMI 1640 were incubated in suspension culture, with and without $250 \mathrm{pg} / \mathrm{ml} \mathrm{rGM-CSF}$, and evaluated at $0,24,48$, and $72 \mathrm{~h}$ for cell number, cell cycle status, and expression of cell surface markers (Table III and Fig. 1). The data in Table III show that anti-proliferative effects of rGM-CSF were rapid, with a $44 \%$ decrease in the percentage of cycling cells in combined $S, G_{2}$, and $M$ cell cycle phases within $24 \mathrm{~h}$. The DNA histograms in Fig. 1 show that rGM-CSF results in a selective reduction of cells in $\mathrm{S}, \mathrm{G}_{2}, \mathrm{M}$ cell-cycle phases, suggesting a block in cell cycle progression at $G_{0}$ or $G_{1}$. After $72 \mathrm{~h}$ of incubation, it should be noted that the percentage of cycling cells decreased in control cultures, most likely because of nutrient depletion, although rGM-CSF caused $23 \%$ further reduction in the fraction of cycling cells at this time point.

HLA-DR antigen expression was not induced by rGM-CSF treatment (Table III). There was consistent, low level expression of the Mo2 antigen (6-8\%) in the GM-CSF-treated group at 24, 48, and $72 \mathrm{~h}$. Although the fraction of Mol positive cells increased with GM-CSF treatment, the absolute number of Mo1positive cells per culture slightly increased only at $24 \mathrm{~h}$ of incubation (Table III).

A soluble inhibitor is released by rGM-CSF-treated U937 cells. Since the primary effect of GM-CSF on normal granulocyte-monocyte progenitor cells is to promote proliferation, we considered the possibility that the unusual antiproliferative effects of rGM-CSF on U937 cell growth might be associated with the

Table III. Effects of rGM-CSF on Proliferation and Differentiation of U937 Cells in Suspension Culture

\begin{tabular}{|c|c|c|c|c|c|c|}
\hline \multirow[b]{2}{*}{ Incubation* time } & \multirow[b]{2}{*}{$\mathrm{rGM}-\mathrm{CSF}(250 \mathrm{pg} / \mathrm{ml})$} & \multirow[b]{2}{*}{ Cell no.: $\left(\times 10^{5} / \mathrm{ml}\right)$} & \multirow[b]{2}{*}{$\mathrm{S}, \mathrm{G} 2$, and $\mathrm{M}^{3}$} & \multicolumn{3}{|c|}{ Percent positive" } \\
\hline & & & & HLA-DR & Mol & Mo2 \\
\hline$h$ & & & $\%$ & $\%$ & $\%$ & $\%$ \\
\hline 0 & - & $3.0 \pm 0.2$ & 48 & 3 & 21 & 0 \\
\hline \multirow{2}{*}{24} & - & $5.35 \pm 0.6$ & 46 & 4 & 22 & 0 \\
\hline & + & $3.34 \pm 0.2$ & 26 & 3 & 52 & 7 \\
\hline \multirow{2}{*}{48} & - & $8.05 \pm 0.5$ & 42 & 3 & 27 & 0 \\
\hline & + & $4.13 \pm 0.4$ & 23 & 2 & 45 & 6 \\
\hline \multirow{2}{*}{72} & - & $8.98 \pm 0.7$ & 30 & 3 & 43 & 0 \\
\hline & + & $2.25 \pm 0.3$ & 23 & 4 & 58 & 8 \\
\hline
\end{tabular}

* U937 cells were incubated in 10\% FBS with RPMI 1640 at an initial concentration of $3 \times 10^{5} / \mathrm{ml}$ in Linbro 24-well plates as described. ${ }^{\ddagger}$ Expressed as mean \pm SEM of two successive determinations of viable cell concentration per sample. ${ }^{8}$ Percentage of cells in combined $S, G_{2}$, and $M$ cell cycle phases as determined by PARA-1 analysis of DNA histograms (see Fig. 1). "Percent positivity after subtracting background fluorescence as determined by indirect immunofluorescence and flow cytometry. 
CONTROL

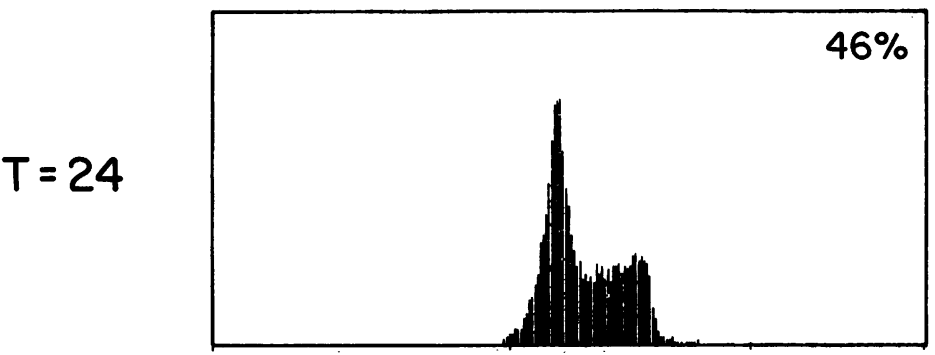

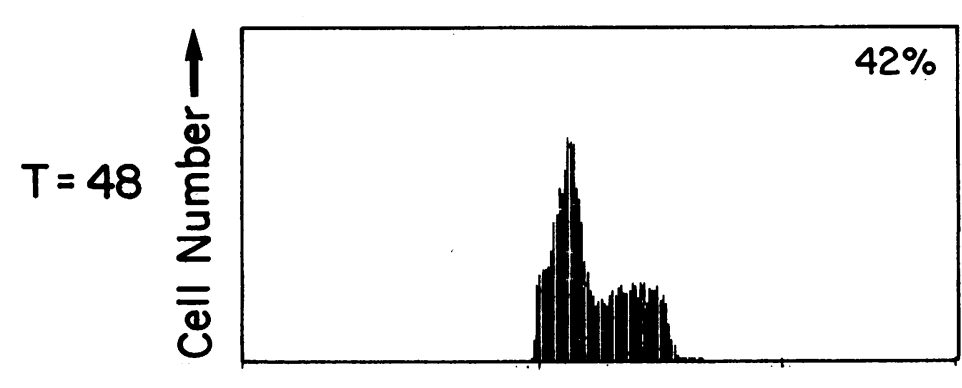
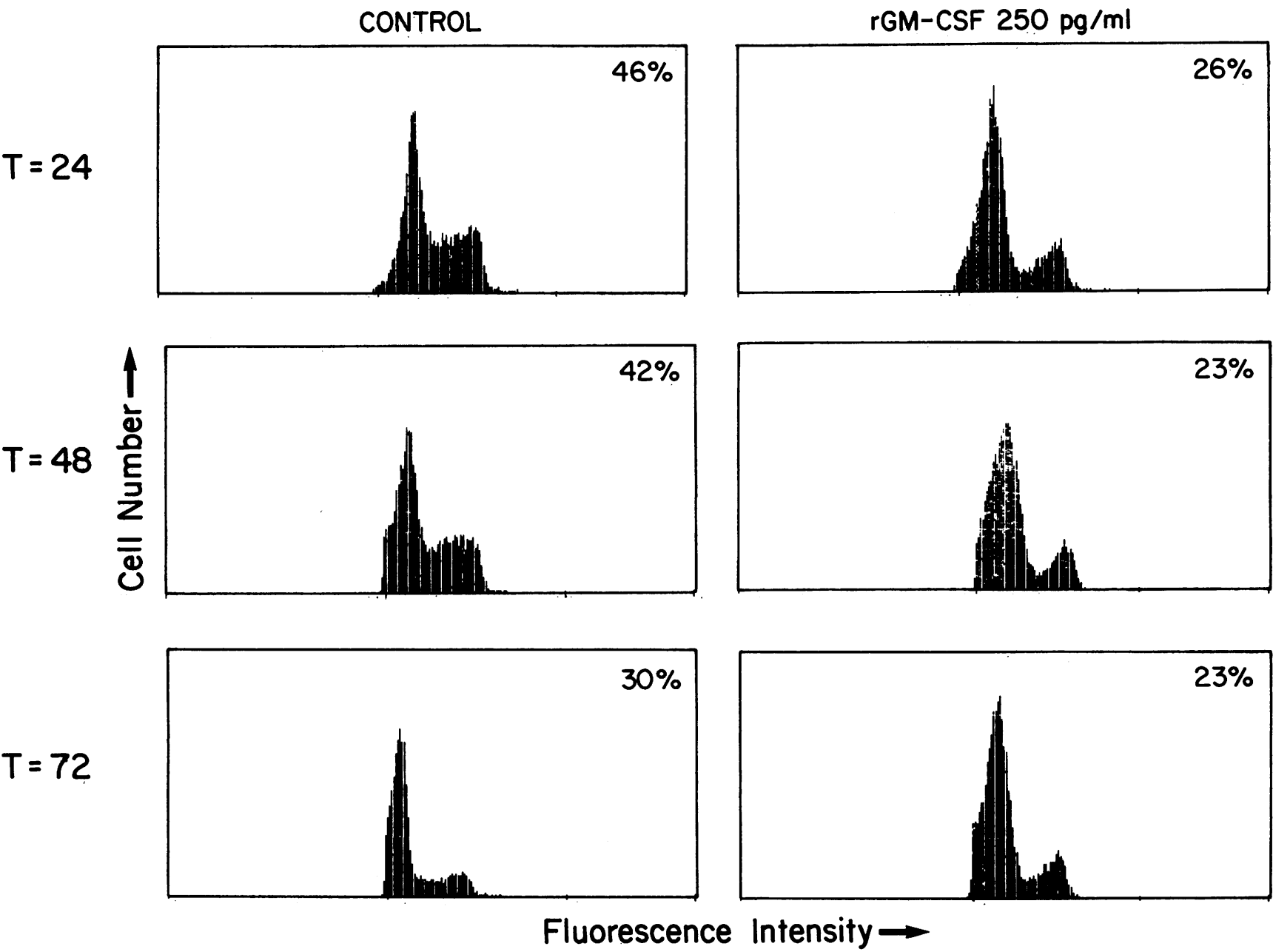

Figure 1. Effect of rGM-CSF on cell cycle status of U937 cells. Cells were incubated in 10\% FBS with RPMI 1640, with or without $250 \mathrm{pg} / \mathrm{ml}$ rGM-CSF, at an initial concentration of $3 \times 10^{5} / \mathrm{ml}$ and were stained with propidium iodide at indicated time points as described in text. Number in upper right-hand corner indicates percentage of cells in $S, G_{2}$, and $M$ cell cycle phase.

release of an inhibitory factor. To evaluate this possibility, CM were prepared by using 10\% FBS with RPMI 1640, with and without U937 cells $\left(2.5 \times 10^{5} / \mathrm{ml}\right)$, and with or without rGMCSF $(250 \mathrm{pg} / \mathrm{ml})$. Cell-free supernatants were collected at 24 and $48 \mathrm{~h}$ and were subsequently added to agar culture (final concentration of $10 \% \mathrm{vol} / \mathrm{vol}$ ) to assess their effects on U937 colony growth. The effects of carry-over rGM-CSF (final concentration $25 \mathrm{pg} / \mathrm{ml}$ in agar) were neutralized by a $1: 100$ dilution of anti-GM-CSF sheep antiserum before plating. This concentration of anti-GM-CSF was shown in pilot studies to neutralize the effects of $>100 \mathrm{pg} / \mathrm{ml}$ rGM-CSF. As shown in Table IV, media conditioned alone (10\% FBS with RPMI 1640) exerted no inhibitory effects on subsequent U937 colony growth. Media conditioned with $250 \mathrm{pg} / \mathrm{ml}$ rGM-CSF, in the absence of U937 cells, resulted in $\sim 48 \%$ inhibition of U937 colony growth (final concentration of $10 \%$, vol/vol), and this inhibitory effect was completely blocked by treatment of CM with anti-GM-CSF sheep antiserum. Media conditioned with U937 cells, without rGM-CSF, did not significantly inhibit U937 colony growth. In contrast, media conditioned with U937 cells plus rGM-CSF exhibited a profound inhibitory effect that could not be reversed by treatment with anti-GM-CSF sheep antiserum, suggesting the presence of an inhibitor distinct from rGM-CSF that was induced within $24 \mathrm{~h}$ of culture (Table IV).

Inhibitory activity of media conditioned with U937 cells plus rGM-CSF is partly related to secretion of TNF. Since the U937 cell line is derived from macrophage lineage cells, we considered the possibility that the soluble inhibitor(s) demonstrated in the above experiments could be a monokine such as TNF, IL-1 alpha and beta, or PGE. The inhibitory effects of each of these monokines on U937 colony growth were tested in agar culture, with results expressed as the ID so $_{\text {in }}$ moles per liter. Neither rIL1 alpha or beta inhibited U.937 colony growth at the highest concentration tested, $10 \mathrm{U} / \mathrm{ml}$ PGE $_{1}$ was moderately inhibitory to U937 colony growth, with an IDso of $1.0 \times 10^{-8} \mathrm{M}$. However, it is unlikely that secretion of PGE was responsible for the inhibitory effects of $\mathrm{U} 937 \mathrm{CM}$, since $10^{-6} \mathrm{M}$ indomethacin was used in the preparation of all CM used in these experiments.

The most inhibitory monokine tested was TNF, with an IDso of $2.7 \times 10^{-11} \mathrm{M}$; we therefore evaluated the influence of antiTNF antibody on the inhibitory effects of media conditioned with rGM-CSF-treated U937 cells (Fig. 2). Media were conditioned with U937 cells plus or minus rGM-CSF as previously described, collected at $24 \mathrm{~h}$ of incubation, and treated with a 
Table IV. Secretion of a Soluble Inhibitor by U937 Cells in Response to rGM-CSF

\begin{tabular}{|c|c|c|c|c|c|}
\hline \multirow{3}{*}{$\begin{array}{l}\text { Media } \\
\text { conditioned } \\
\text { for }\end{array}$} & \multirow[b]{3}{*}{ Anti-rGM-CSF $A^{\ddagger}$} & \multicolumn{4}{|c|}{ Colonies per $5 \times 10^{2}$ U937 cells } \\
\hline & & \multicolumn{4}{|c|}{ Source of CM $(10 \% \mathrm{vol} / \mathrm{vol})^{*}$} \\
\hline & & Media aloṇe & Media + rGM-CSF & U937 & $\mathrm{U} 937+\mathrm{rGM}-\mathrm{CSF}$ \\
\hline \multicolumn{6}{|l|}{$\boldsymbol{h}$} \\
\hline \multirow{2}{*}{24} & - & $320 \pm 26^{8}$ & $153 \pm 18(48)^{\prime \prime}$ & $280 \pm 31$ & $3 \pm 1(99)$ \\
\hline & + & $317 \pm 35$ & $324 \pm 35(-2)$ & $275 \pm 29$ & $23 \pm 3(92)$ \\
\hline \multirow{2}{*}{48} & - & $324 \pm 21$ & $159 \pm 21(51)$ & $225 \pm 26$ & $1 \pm 1(99)$ \\
\hline & + & $318 \pm 30$ & $309 \pm 28(3)$ & $235 \pm 19$ & $10 \pm 3(96)$ \\
\hline
\end{tabular}

* Media (10\% FBS with RPMI 1640) was conditioned as indicated for 24 or $48 \mathrm{~h}$ and added to the double layer colony assay at a final concentration of $10 \% \mathrm{vol} / \mathrm{vol}$. ${ }^{\ddagger}$ Anti-GM-CSF sheep antiserum at a final dilution of $1: 100$ was added to $\mathrm{CM}$ as indicated for $1 \mathrm{~h}$ at $25^{\circ} \mathrm{C}$ to neutralize rGM-CSF before plating. AB, antibody. ${ }^{8}$ Results are expressed as mean $\pm S E M$ of triplicate cultures. "Numbers in parentheses indicate percent inhibition.

1:100 dilution of anti-GM-CSF sheep antiserum plus either 100 $\mu \mathrm{g} / \mathrm{ml}$ anti-IFN gamma antibody (used as a control antibody) or $100 \mu \mathrm{g} / \mathrm{ml}$ anti-TNF antibody. CM that were treated in this fashion were then added to agar colony assays (final concentration $5 \% \mathrm{vol} / \mathrm{vol}$ ) to assess inhibitory effects on U937 colony growth. Colony growth was not affected by the presence or ab-

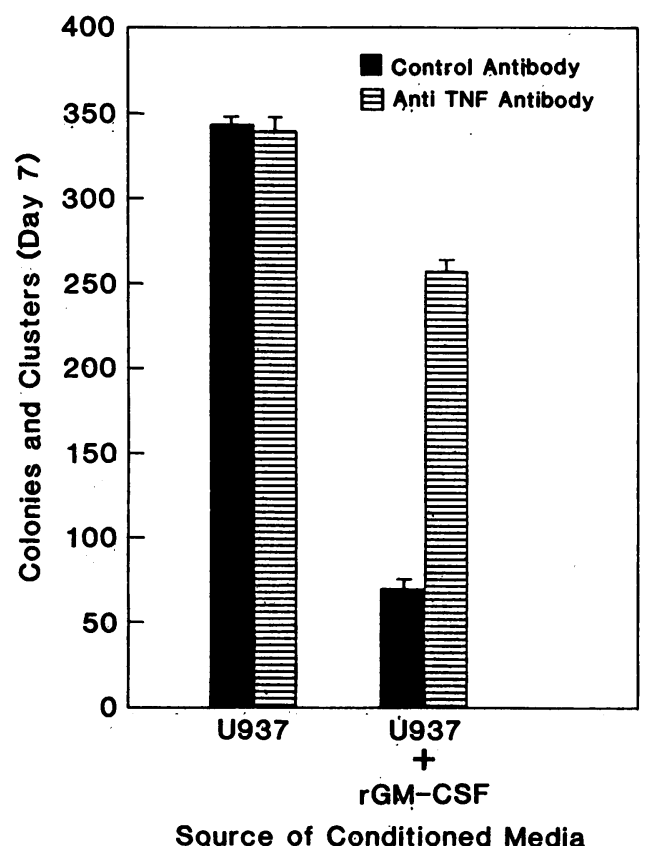

Figure 2. Influence of anti-TNF antibody on the inhibitory effect of media conditioned with U937 and rGM-CSF. Media were conditioned with either U937 cells alone, or U937 cells and rGM-CSF (250 pg/ $\mathrm{ml})$, for $24 \mathrm{~h}$. Cell-free supernatants were collected and treated with anti-GM-CSF sheep serum (1:100 dilution), plus either control antibody $(100 \mu \mathrm{g} / \mathrm{ml}$ anti-IFN-gamma) or $100 \mu \mathrm{g} / \mathrm{ml}$ anti-TNF antibody for $1 \mathrm{~h}$ at $25^{\circ} \mathrm{C}$. CM were then added (final concentration $5 \% \mathrm{vol} / \mathrm{vol}$ ) to the double-layer colony assay to assess inhibitory effects on U937 colony growth. Results are from one of three representative experiments. sence of control antibody, regardless of the source of CM (data not shown). As shown in Fig. 2, anti-TNF antibody did not affect baseline U937 colony growth in the presence of media conditioned by U937 cells alone. Media conditioned with U937 cells and rGM-CSF was inhibitory to U937 colony growth in the presence of control antibody, but this inhibitory effect was partially reversed in the presence of anti-TNF antibody. These results suggest that TNF was secreted by U937 cells in response to GM-CSF and was partly responsible for the inhibitory effects of media conditioned with rGM-CSF-treated U937 cells. To determine the role of rGM-CSF-induced TNF secretion in the inhibition of U937 colony growth, $100 \mu \mathrm{g} / \mathrm{ml}$ anti-TNF-antibody was directly added to agar culture in the presence of 50 or $250 \mathrm{pg} / \mathrm{ml} \mathrm{rGM-CSF}$, and U937 colony growth was assessed at day seven. As shown in Table V, anti-TNF-antibody did not significantly alter the inhibitory effects of rGM-CSF on U937 colony growth. This suggests that other soluble inhibitors may mediate this inhibitory effect, that rGM-CSF may exert direct antiproliferative effects on U937 cell growth that are distinct

Table V. Influence of Anti-TNF Monoclonal Antibody on U937. Colony Inhibition by rGM-CSF

\begin{tabular}{llll}
\hline & \multicolumn{3}{l}{ Colonies per $5 \times 10^{2}$ U937 cells* } \\
\cline { 2 - 4 } Treatment & \multicolumn{2}{c}{ Control (media) } & $\begin{array}{l}\text { Anti-TNF antibody } \\
(100 \mu \mathrm{g} / \mathrm{ml})\end{array}$ \\
\hline Media $^{\ddagger}$ & $263 \pm 19^{8}$ & $251 \pm 21$ \\
rTNF $(100 \mathrm{U} / \mathrm{ml})$ & 0 & $(100)^{\prime \prime}$ & $163 \pm 18(35)$ \\
rTNF $(10 \mathrm{U} / \mathrm{ml})$ & $79 \pm 5$ & $(70)$ & $220 \pm 19(12)$ \\
rGM-CSF $(250 \mathrm{pg} / \mathrm{ml})$ & $47 \pm 5$ & $(82)$ & $51 \pm 7(80)$ \\
rGM-CSF $(50 \mathrm{pg} / \mathrm{ml})$ & $92 \pm 7$ & $(65)$ & $97 \pm 10(61)$ \\
\hline
\end{tabular}

* U937 cells were incubated in agar culture as previously described, in the presence or absence of anti-TNF antibody as indicated.

‡10\% FBS with RPMI 1640.

${ }^{\S}$ Results expressed as mean \pm SEM colonies of triplicate cultures at day seven.

"Numbers in parentheses indicate percent inhibition. 
from its ability to induce TNF secretion, or that it is not possible to add sufficient anti-TNF antibody to observe effects in a 7-d agar culture.

rGM-CSF induces expression of the TNF gene in U937 cells and in normal human monocytic cells. To determine if the secretion of TNF by U937 cells was associated with induction of the TNF gene by rGM-CSF, U937 cells were cultured at a starting density of $2.5 \times 10^{5}$ cells/ml 10\% FBS with RPMI 1640, with and without $2,500 \mathrm{pg} / \mathrm{ml}$ rGM-CSF or $10^{-10} \mathrm{M}$ PMA, and total cellular RNA was extracted at varying time points. The RNA was fractionated on agarose gels, blotted onto synthetic membranes, and TNF-specific messenger RNA (mRNA) was detected by using a ${ }^{32} \mathrm{P}$-labeled TNF-specific cDNA probe. Ethidium bromide staining of agarose gels that were used in these studies revealed equivalent amounts of RNA in each lane as assessed by the staining pattern of $18 \mathrm{~S}$ and $28 \mathrm{~S}$ ribosomal RNA bands (data not shown). As shown in Fig. 3, TNF message was induced by rGM-CSF as early as $2 \mathrm{~h}$, with peak expression at $6 \mathrm{~h}$ and with detectable levels present at 18 and $24 \mathrm{~h}$. The size of the TNF message detected in U937 cells was similar to that previously reported for PMA-induced HL60 cells (19). The induction of TNF message by PMA was quantitatively greater than that seen with rGM-CSF, although the size of the message and the kinetics of expression were similar (Fig. 3).

Since U937 cells have monocytic characteristics, we studied the ability of rGM-CSF to induce TNF gene expression in normal monocytic cells. To minimize monocyte activation as a result of plastic adherence, E-negative, nonadhered peripheral blood cells were used as a source of human monocytes and were cultured at $2 \times 10^{6}$ cells $/ \mathrm{ml}$ for $18 \mathrm{~h}$ at $37^{\circ} \mathrm{C}$ in slanted $250-\mathrm{ml}$ polypropylene tubes (Corning Glass Works, Corning Science Products, Corning, NY), with media, mock CSF, or $2,500 \mathrm{pg} /$ $\mathrm{ml}$ rGM-CSF. Polypropylene tubes were used because inactivated human monocytes do not adhere to this surface. Cell recovery and viability was $>90 \%$ in all treatment groups. After $18 \mathrm{~h}$ of incubation, a small amount of TNF message was detectable in E-negative cells exposed to either media or mock CSF (Fig. 4).

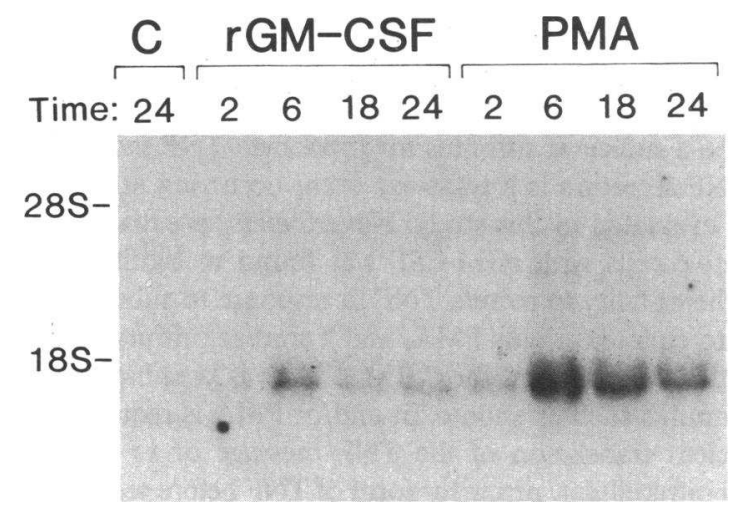

Figure 3. Northern blot analysis of U937 mRNA. U937 cells were incubated in 10\% FBS with RPMI 1640 plus or minus rGM-CSF $(2,500$ $\mathrm{pg} / \mathrm{ml})$, or plus or minus PMA $\left(10^{-10} \mathrm{M}\right)$ and collected at indicated time points as described in text. Total cellular RNA was isolated and Northern blot analysis was performed by using the ${ }^{32} \mathrm{P}$-labeled Pst-I fragment of the human TNF cDNA as described in Methods. C, control medium.

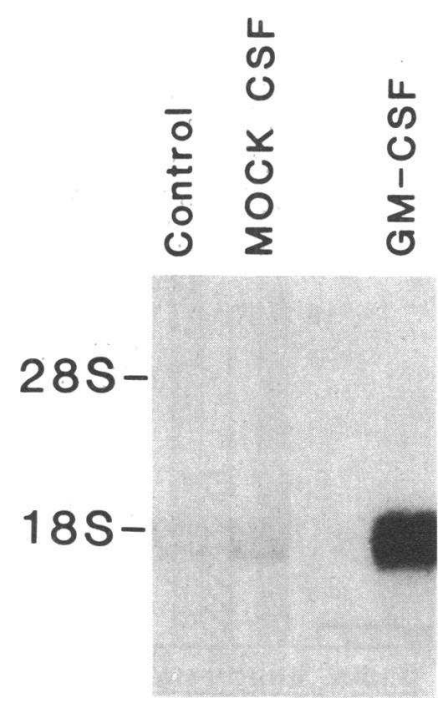

Figure 4. Northern blot analysis of total cellular RNA extracted from monocyte-enriched peripheral blood cells that were incubated in $10 \%$ FBS with RPMI 1640 plus or minus control media, mock $\mathrm{CSF}$, or rGM-CSF $(2,500 \mathrm{pg} /$ $\mathrm{ml}$ ) and collected at $18 \mathrm{~h}$. TNF mRNA was detected as described in Fig. 3.

However, significant induction of TNF gene expression was observed in E-negative cells that were exposed to rGM-CSF. As previously stated, the endotoxin concentrations of media, mock CSF, and rGM-CSF were similar, $0.3-0.5 \mathrm{ng} / \mathrm{ml}$, which made it unlikely that the enhanced expression of the TNF gene observed with rGM-CSF was due to contaminating endotoxin.

rGM-CSF primes normal human monocytic cells to secrete $T N F$ in response to endotoxin and PMA. To evaluate the effects of rGM-CSF on monocyte TNF secretion, E-negative cells were first cultured at $5 \times 10^{6}$ cells/ml 10\% FCS with RPMI 1640 in Linbro 24-well plates with media, rGM-CSF $(2,500 \mathrm{pg} / \mathrm{ml})$, heatinactivated $\mathrm{rGM}-\mathrm{CSF}\left(100^{\circ} \mathrm{C}\right.$ for $\left.1 \mathrm{~h}\right)$, or mock CSF for either 18 or $72 \mathrm{~h}$. Cell-free supernatants were collected, and TNF was measured by ELISA assay as described. In four separate donors tested, no TNF was detected at 18 or $72 \mathrm{~h}$ in any of the four treatment groups outlined above (data not shown). We next considered the possibility that GM-CSF may prime monocytes to secrete TNF in response to a combination of endotoxin and PMA, a known stimulus of TNF secretion (22). Therefore, monocytes in each of the four treatment groups were incubated for $18 \mathrm{~h}$, washed three times, and divided into two equal fractions that contained either media alone or media plus endotoxin ( 100 $\mathrm{ng} / \mathrm{ml}$ ) and $10^{-11} \mathrm{M}$ PMA. Cell recovery, viability, and number were equivalent in each of the four treatment groups. Cell-free supernatants were collected after $48 \mathrm{~h}$, and TNF was measured by ELISA assay with the results shown in Fig. 5. In four separate donors tested, E-negative cells preincubated in media alone (18 h) secreted only a small amount of TNF when exposed to endotoxin and PMA for $48 \mathrm{~h}$. In contrast, E-negative cells that were preincubated with $2,500 \mathrm{pg} / \mathrm{ml}$ rGM-CSF secreted greatly enhanced levels of TNF with subsequent endotoxin and PMA exposure. This "priming" effect was specific for rGM-CSF since no effect was observed with preincubation in either heat-inactivated rGM-CSF or mock CSF (Fig. 5).

\section{Discussion}

GM-CSF is an important growth factor for the proliferation and differentiation of early myeloid progenitor cells, although it also 


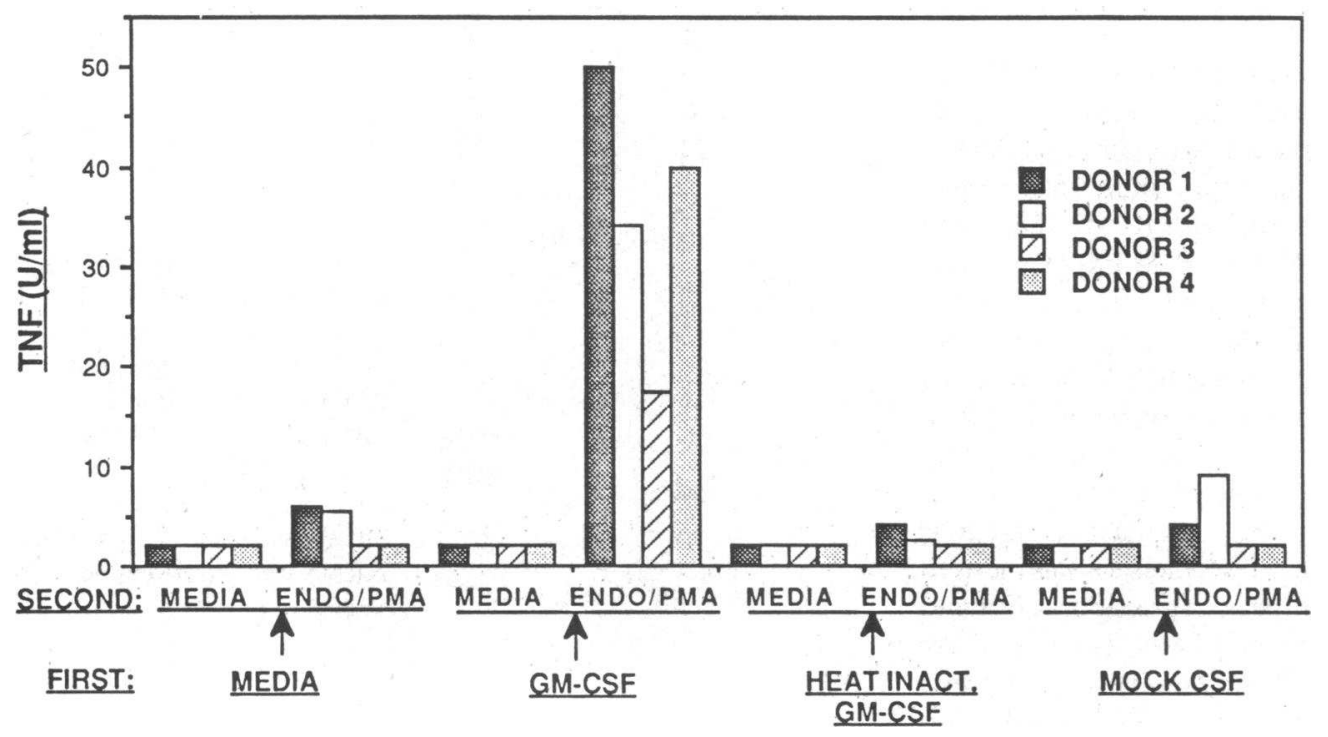

Figure 5. Effects of preincubation with rGM-CSF on TNF secretion by E-negative cells. $5 \times 10^{6}$ cells/ $\mathrm{ml}$ were first incubated for $18 \mathrm{~h}$ in media (10\% FCS with 1640), rGM-CSF $(2,500 \mathrm{pg} / \mathrm{ml})$, heat-inactivated $\mathrm{rGM}-\mathrm{CSF}\left(100^{\circ} \mathrm{C}\right.$ for 1 h), or mock CSF. Each treatment group was then washed three times, counted, and split into two equal fractions that were exposed to either media or endotoxin $(100 \mathrm{ng} / \mathrm{ml})$ plus PMA $\left(10^{-11} \mathrm{M}\right)$ for a second incubation period (cell concentration $\sim 2.5 \times 10^{6}$ cells $/ \mathrm{ml}$ ). After 48 $h$, cell-free supernatants were collected and TNF concentration was determined by ELISA assay as described in text. Results are expressed as the mean of triplicate determinations, with SE of $<10 \%$ for all values shown. exerts a wide variety of biological effects on mature cells of the granulocyte-macrophage cell lineage. For example, GM-CSF has been shown to enhance cytotoxicity of neutrophils, eosinophils, and macrophages for tumor target cells $(5,23)$, to enhance phagocytic activity of neutrophils (4), and to induce inhibition of neutrophil migration (3). Also, GM-CSF induces the killing of schistosomula by neutrophils and eosinophils (24), as well as the intracellular killing of Leishmania by macrophages (25).

In this study, we have investigated the functional effects of GM-CSF on monocytic cells by utilizing the U937 cell line as a model system for the study of macrophage-like cells in vitro. Previous studies have shown that U937 cells are capable of expressing many monocytic functions, such as antibody-dependent cytotoxicity after activation by supernatants from human mixed lymphocyte cultures (7). Also, we have previously shown that both human monocytes and U937 cells display similar responses to IFN-gamma treatment that include induction of HLA-DR antigen expression, increased intensity of nonspecific esterase staining, increased adherence, and surface expression of the gp 55-60 IL-2 receptor (26). The present report demonstrates that rGM-CSF rapidly induces TNF gene expression and TNF secretion by the monocytic cell line U937. Although TNF is markedly inhibitory to U937 colony growth in agar, our experiments do not allow us to conclude that TNF is responsible for the inhibitory effects of GM-CSF on U937 cell proliferation in agar culture. For instance, the observation that high concentrations of anti-TNF-antibody added directly to agar culture did not alter the inhibitory effects of rGM-CSF suggests that TNF secretion may have little or no role in mediating this in vitro phenomenon. It is possible that other inhibitory factors are also secreted by U937 cells in response to GM-CSF that might contribute to the antiproliferative effects observed in this study. Alpha or beta interferon, for example, would be candidates for such inhibitory factors, and future studies will be necessary to address this possibility. It is also possible that the suppressive effects of GM-CSF in this system occur by direct mechanisms, such as partial differentiation, which are distinct from indirect antiproliferative effects of GM-CSF that are due to induction of soluble inhibitors.

A variety of stimuli that induce the secretion of TNF in vitro have been defined. For instance, monocytes and a number of cell lines that include U937 and HL60 secrete TNF after exposure to LPS and/or PMA $(27,28)$. Also, the secretion of TNF by human peripheral blood mononuclear cells can be stimulated by a combination of mitogens plus IL-2, and TNF production in this system is enhanced in the presence of IFN-gamma (28). Furthermore, Sendai virus infection has been recently found to induce TNF secretion by human mononuclear cells (29). To our knowledge, however, this is the first report that demonstrates the ability of the T cell lymphokine GM-CSF (30) to induce TNF secretion in macrophage-like cells.

In this study, we have also shown that rGM-CSF enhances TNF gene expression in the monocyte-enriched fraction of normal peripheral blood. However, TNF secretion by normal human E-negative cells was not detected after exposure to rGMCSF for either 18 or $72 \mathrm{~h}$. This suggests that GM-CSF by itself may not be a sufficient stimulus for monocyte TNF secretion, or that TNF secretion is a transient event occurring at a time point not evaluated in this study. Nevertheless, preincubation of E-negative cells with rGM-CSF was found to significantly enhance their ability to secrete TNF in response to subsequent exposure to endotoxin plus PMA, and a similar priming effect has recently been reported for CSF-1 (22). It is possible that a second stimulus such as endotoxin and/or PMA is required to effect efficient translation of the TNF message or to further modify an intracellular, precursor form of TNF before secretion. Experiments are currently being performed to evaluate these possibilities.

These data suggest that GM-CSF may play a central role in the local immune response. GM-CSF is a lymphokine secreted by activated $\mathrm{T}$ cells, and it may be one of the factors responsible for priming monocytes to secrete TNF in response to a second 
stimulus, perhaps physiologically provided by endotoxin. TNF, in turn, has been shown to enhance neutrophil adherence (31), as well as to kill schistosomula by eosinophils (32). It has also recently been demonstrated that IGM-CSF induces macrophage tumoricidal activity (5), and that tumor cell killing by activated macrophages may be mediated by TNF (33). Altogether, these data suggest that some of the biological effects of GM-CSF on differentiated myeloid cells may be amplified through induction of TNF secretion. Also, TNF is inhibitory to the growth of myeloid progenitor cells, especially in the presence of IFN-gamma $(34,35)$, and stimulation of TNF secretion by macrophages in response to GM-CSF may act as a negative feedback circuit in the control of myeloid-cell growth. Further studies of the effect of GM-CSF on TNF secretion by human monocytes will be necessary to better understand the extent to which GM-CSF and TNF may interact in the control of host defense mechanisms and in the regulation of hematopoiesis.

\section{Acknowledgments}

This work was supported in part by U.S. Public Health Service grants CA07765, CA36167, and CA19389 project three. Dr. Rambaldi is supported by a fellowship from the Italian Association for Cancer Research. Dr. Griffin is a Scholar of the Leukemia Society of America.

\section{References}

1. Wong, G. G., J. S. Witek, P. A. Temple, K. M. Wilkens, A. C. Leary, D. P. Luxenberg, S. S. Jones, E. L. Brown, R. M. Kay, E. C. Orr, C. Shoemaker, D. W. Golde, R. J. Kaufman, R. M. Hewick, E. A. Wang, and S. C. Clark. 1985. Human GM-CSF: molecular cloning of the complementary DNA and purification of the natural and recombinant proteins. Science (Wash. DC). 229:810-815.

2. Sieff, C. A., S. G. Emerson, R. E. Donahue, and D. G. Nathan 1985. Human recombinant granulocyte-macrophage colony-stimulating factor: a multilineage hematopoietin. Science (Wash. DC). 230:11711173.

3. Gasson, J. C., R. H. Weisbart, S. E. Kaufman, S. C. Clark, R. M. Hewick, G. G. Wong, and D. W. Golde. 1984. Purified human granulocyte-macrophage colony-stimulating factor: direct action on neutrophils. Science (Wash. DC). 226:1339-1342.

4. Metcalf, D., C. G. Begley, G. R. Johnson, N. A. Nicola, M. A. Vadas, A. F. Lopez, D. J. Williamson, G. G. Wong, S. C. Clark, and E. A. Wang. 1986. Biologic properties in vitro of a recombinant human granulocyte-macrophage colony-stimulating factor. Blood. 67:37-45.

5. Grabstein, K. H., D. L. Urdal, R. J. Tushinski, D. Y. Mochizuki, V. L. Price, M. A. Cantrell, S. Gillis, and P. J. Coulon. 1986. Induction of macrophage tumoricidal activity by granulocyte-macrophage colonystimulating factor. Science (Wash. DC). 232:506-508.

6. Gasson, J. C., S. E. Kaufman, R. H. Weisbart, M. Tomonaga, and D. W. Golde. 1986. High affinity binding of granulocyte-macrophage colony-stimulating factor to normal and leukemic human myeloid cells. Proc. Natl. Acad. Sci. USA. 83:669-673.

7. Koren, H. S., S. J. Anderson, J. W. Larrick. 1979. In vitro activation of a human macrophage-like cell line. Nature (Lond.). 279:328-331.

8. Collins, S. J., R. C. Gallo, and R. E. Gallagher. 1977. Continuous growth and differentiation of human myeloid leukemic cells in suspension culture. Nature (Lond.). 270:347-350.

9. Koeffler, H. P., and D. W. Golde. 1978. Acute myelogenous leukemia: a human cell line responsive to colony-stimulating activity. Science (Wash. DC). 200:1153-1156.
10. Lozzio, C. B., and B. B. Lozzio. 1975. Human chronic myelogenous leukemia cell-line with positive Philadelphia chromosome. Blood. 45:321-334.

11. Klein, E., G. Klein, J. S. Nadkarni, J. J. Nadkarni, H. Wigzell, and P. Clifford. 1968. Surface IgM-kappa specificity on a Burkitt lymphoma cell line in vivo and in derived culture lines. Cancer Res. 28: $1300-1310$.

12. Griffin, J. D., and S. F. Schlossman. 1984. Human Leukocyte Differentiation Antigens Detected by Monoclonal Antibodies. In Leukocyte Typing. Specification-Classification-Nomenclature. A. Bernard, L. Boumsell, J. Dausset, C. Milstein, S. F. Schlossman, editors. SpringerVerlag, New York. 404-410.

13. Shirai, T., H. Yamaguchi, I. Hirataka, C. W. Todd, and R. B. Wallace. 1985. Cloning and expression in Escherichia coli of the gene for human tumour necrosis factor. Nature (Lond.). 313:803-806.

14. Herrmann, F., S. A. Cannistra, and J. D. Griffin. 1986. T cellmonocyte interactions in the production of humoral factors regulating human granulopoiesis in vitro. J. Immunol. 136:2856-2861.

15. Cannistra, S. A., F. Herrmann, R. Davis, K. Nichols, and J. D. Griffin. 1986. Relationship between HLA-DR expression by normal myeloid progenitor cells and inhibition of colony growth by prostaglandin E. Implications for prostaglandin E resistance in chronic myeloid leukemia. J. Clin. Invest. 77:13-20.

16. Cannistra, S. A., J. F. Daley, P. Larcom, and J. D. Griffin. 1985. Expression of la antigens on myeloid progenitor cells in chronic myeloid leukemia. Direct analysis using partially purified colony-forming cells. Blood. 65:414-422.

17. Defranco, A. L., E. S. Raveche, R. Asofsky, and W. E. Paul. 1982. Frequency of B lymphocytes responsive to anti-immunoglobulin. J. Exp. Med. 155:1523-1536.

18. Maniatis, T., E. F. Fritsch, and J. Sambrook. 1982. Molecular Cloning - a laboratory manual. Cold Spring Harbor Laboratory Publication, Cold Spring Harbor. 545 pp.

19. Wang, A. M., A. A. Creasey, M. B. Ladner, L. S. Lin, J. Strickler, Van J. N. Arsdell, R. Yamamoto, and D. F. Mark. 1985. Molecular cloning of the complementary DNA for human tumor necrosis factor. Science (Wash. DC). 228:149-154.

20. Feinberg, A. P., and B. Vogelstein. 1983. A technique for radiolabelling DNA restriction endonuclease fragments to high specific activity. Anal. Biochem. 132:6-11.

21. Hayashi, H., T. Kiyota, H. Sakamoto, and M. Seto. 1985. An enzyme-linked immunosorbent assay for recombinant human tumor necrosis factor using monoclonal antibody. In Recent Advances in Chemotherapy. J. Ishigami, editor. University of Tokyo Press, Tokyo, Japan. 820-821.

22. Warren, M. K., and P. Ralph. 1986. Macrophage growth factor CSF-1 stimulates human monocyte production of interferon, tumor necrosis factor, and colony stimulating activity. J. Immunol. 137:22812285.

23. Vadas, M. A., N. A. Nicola, and D. Metcalf. 1983. Activation of antibody-dependent cell-mediated cytotoxicity of human neutrophils and eosinophils by separate colony-stimulating factors. J. Immunol. 130:795799.

24. Dessein, A., M. A. Vadas, N. Nicola, D. Metcalf, and J. R. David. 1982. Activation of human blood eosinophils by human placental conditioned medium and by semi-purified eosinophil colony-stimulating factor. J. Exp. Med. 156:90-99.

25. Handman, E., and A. W. Burgess. 1979. Stimulation by granulocyte-macrophage colony-stimulating factor of Leishmania tropica killing by macrophages. J. Immunol. 122:1134-1137.

26. Herrmann, F., S. A. Cannistra, H. Levine, and J. D. Griffin. 1985. Expression of interleukin-2 receptors and binding of interleukin2 by gamma-interferon-induced human leukemic and normal monocytic cells. J. Exp. Med. 162:1111-1116.

27. Williamson, B. D., E. A. Carswell, B. Y. Rubin, J. S. Prendergast, 
and L. J. Old. 1983. Human tumor necrosis factor produced by human B-cell lines: synergistic cytotoxic interaction with human interferon. Proc. Natl. Acad. Sci. USA. 80:5397-5401.

28. Nedwin, G. E., L. P. Svedersky, T. S. Bringman, M. A. Palladino, and D. V. Goeddel. 1985. Effect of interleukin-2, interferon-gamma, and mitogens on the production of tumor necrosis factors alpha and beta. J. Immunol. 135:2492-2497.

29. Aderka, D., H. Holtmann, L. Toker, T. Hahn, and D. Wallach. 1986. Tumor necrosis factor induction by Sendai virus. J. Immunol. 136:2938-2942.

30. Griffin, J. D., S. C. Meuer, S. F. Schlossman, and E. L. Reinherz. 1984. T cell regulation of myelopoiesis: analysis at a clonal level. $J$. Immunol. 133:1863-1868.

31. Shalaby, R. M., B. B. Aggarwal, E. Rinderknecht, P. L. Sverdersky, S. B. Finkel, and A. M. Palladino. 1985. Activation of human polymorphonuclear neutrophil functions by interferon-gamma and tumor necrosis factor. J. Immunol. 135:2069-2074.
32. Silberstein, D. S., and J. R. David. 1986. Tumor necrosis factor enhances eosinophil toxicity to Schistosoma mansoni larvae. Proc. Natl. Acad. Sci. USA. 83:1055-1059.

33. Urban, J. L., M. Shepard, J. L. Rothstein, B. J. Sugarman, and H. Schreiber. 1986. Tumor necrosis factor: a potent effector molecule for tumor cell killing by activated macrophages. Proc. Natl. Acad. Sci. USA. 83:5233-5237.

34. Broxmeyer, H. E., D. E. Williams, L. Lu, S. Cooper, S. Anderson, G. S. Beyer, R. Hoffman, and B. Y. Rubin. 1986. The suppressive influences of human tumor necrosis factors on bone marrow hematopoietic progenitor cells from normal donors and patients with leukemia: synergism of tumor necrosis factor and interferon-gamma. J. Immunol. 136: 4487-4495.

35. Beran, M., B. S. Anderson, J. Gutterman, and K. B. McCredie. 1985. Recombinant tumor necrosis factor (TNF-r) is highly effective in inhibiting leukemic clonogenic growth in vitro while being moderately inhibitory to normal GM-CFC. Blood. 66:218a. (Abstr.) 